\title{
Making Medicine Care
}

\section{Raymond De Vries ${ }^{1}$}

Published online: 18 March 2019

(C) The Author(s) 2019

\begin{abstract}
In their book, Hostility to Hospitality, Michael and Tracy Balboni describe the social and historical forces that have conspired to separate religion from the practice of medicine. Seeing the harm in that separation, and offering evidence that both patients and clinicians are open to more of a religious and spiritual presence in caregiving, the authors propose a strategy for reintroducing religion to the clinic. Progress toward their commendable goal of "restoring hospitality to medicine" would be facilitated by a more complete understanding of how secular and sacred spiritualties inform the practice of medicine, analysis of the parallels between the introduction of ethics and the demise of religion in medicine, and consideration of the predictable problems with "structural pluralism," the authors' proposal for reuniting religion and medicine.
\end{abstract}

Keywords Religion $\cdot$ Medicine $\cdot$ Spirituality $\cdot$ Bioethics $\cdot$ Sociology

Michael and Tracy Balboni's Hostility to Hospitality opens with a meditation on three paintings, The Doctor (Fildes, 1890), Science and Charity (Picasso, 1897), and Sentence of Death (Collier, 1908). ${ }^{1}$ In each we see a doctor at work with a patient. Fildes portrays a doctor looking thoughtfully and lovingly at the face of a sick and sleeping child, ministering to his young patient with the force of his character and concern. Picasso offers a different vision of the ministrations of medicine. Here we see a doctor, grasping the wrist of an ailing patient, his gaze fixed, not on the person lying abed, but on his watch. A nun stands by, holding a child in one arm, offering a drink to the patient with the other. Sentence of Death moves out of the sick room into the doctor's office, where the patient - a well-dressed young man - looks out at us, a forlorn expression on his face. The doctor, bearer of difficult news, sits at a distance from the patient, behind a desk arrayed with the instruments of his trade - microscope, stethoscope, and sphygmomanometer - staring down at a book that lies on his desk.

\footnotetext{
${ }^{1}$ Michael J. Balboni and Tracy A. Balboni, Hostility to Hospitality: Spirituality and Professional Socialization within Medicine (New York: Oxford University Press, 2018).
}

Raymond De Vries

rdevries@med.umich.edu

1 Center for Bioethics and Social Sciences in Medicine, University of Michigan, Ann Arbor, MI 48100, USA
Spanning just 18 years, these paintings aptly illustrate the substantial changes in the practice of medicine that occurred at the turn of the last century, a move from "bedside" to "laboratory" medicine, where the art of healing shifted its attention from persons to cells (Jewson 1976). The authors of Hostility to Hospitality, however, see in these images another, perhaps more worrying, change: a growing separation of medicine from spirituality and religion. In their words (p.6): "[T]hese three paintings capture the transfer of spirituality and religion in the context of medicine from the caring physician himself (Fildes) to a religious representative and institutional context (Picasso), before showing the final collapse into its visible absence (Collier)."

The title of their book, "Hostility to Hospitality," is both dispiriting and hopeful. On the one hand, it conveys the authors' concern that "medicine's retreat from spiritual partnership" - its hostility to the hospitality offered by religion - is harmful to both patients and caregivers, leaving "many patients without important resources for [navigating] the experience of illness" and undermining the efforts of clinicians who wish to provide compassionate "personal caregiving" (p. 6). On the other hand, the title reflects the authors' hope that medicine can once again find a place for religion - moving from hostility toward religion to accepting it as a vital part of care.

Balboni and Balboni open their exploration of the religionmedicine relationship by calling on research - their own and others' - to make their case. They present data that: 1) confirm the absence of religion in the halls of medicine (in spite of its value), 2) show that both patients and clinicians would 
welcome more of a religious/spiritual presence in the caregiving relationship, 3) identify the real and perceived institutional barriers that prevent clinicians and patients from invoking religion, and 4) make visible the larger cultural beliefs and social structures that separate medicine and religion.

Of course, there can be no argument for a closer relationship between medicine and religion without an understanding of the boundaries of the religious. While everyone "knows" what religion and spirituality are, precise definitions of these phenomena are still debated. Recognizing this, and in order to provide a socio-theological basis for their position, the authors distinguish definitions of religion that are "substantive" - focusing on content, "emphasizing belief in something superhuman or beyond material reality" (p. 121) - and definitions that are "functional" - considering the role of religion, "emphasizing the relationship that the [religious] system has toward a human need or end" (p. 121). They prefer the latter, drawing on the work of several scholars of religion - including Durkheim, Geertz, Bellah, and Marty.

The functional view allows Balboni and Balboni to make sense of the changing place of religion in medicine and has the additional advantage of opening the door to bringing religion back to medicine. They observe that while religion may have been banished from the medical arena, the nature of medical care - dealing with crises of illness, injury, and death - demands some sort of "spirituality," a way of finding meaning in life's tragedies. Working with a definition of spirituality as "Life centered in the person(s) and/or object(s) of one's chief love [or ultimate concern]" (p.119), they ask: What does the spirituality of medicine look like when stripped of belief in the transcendent? If someone is "spiritual, but not religious," how do they make sense of the work of healing? It is this aspect of the contemporary relationship between medicine and religion that the authors find most troubling. For them, the absence of religion reduces the spirituality of medicine to a spirituality of "immanence," - a "system that intensely values bodily health, cure, and physical comfort as its chief love or telos" (p. 315). This system, in turn, "empowers a death-denying culture, tolerance for the expansion of impersonal medicine, and the medical system's avoidance of patients' religious experience of illness" (p. 315).

The authors' goal is a noble one: to bring traditional moral and spiritual traditions back into medicine in order to help clinicians "rediscover...their deepest commitments to hospitality and compassion in the care of the seriously ill" (p.9). It is a goal I share. Nevertheless, I see problems with the way they make their case, and thus with their proposal for "restoring hospitality to medicine" (p. 219).

I am a sociologist, so it is no surprise that I believe that Balboni and Balboni begin their monograph in the proper place, by asking, "How did we get here? What confluence of cultural and structural change has brought us to this point?" But they miss the opportunity to deepen their analysis by approaching this question as "social reformers." They are eager to bring religion back to the clinic, an eagerness that narrows their search for the causes of (and remedies for) the separation of religion and medicine. In his description of the vocation of sociology, Berger (1963) explains. When a social reformer sees a situation that needs changing, he or she will ask, "What's wrong here?" The sociologist, who may well agree that the situation should be changed, will not begin by looking for what is wrong. Rather, she or he will begin by asking "What's going on here?" The difference is subtle, but social reformers, in their desire to fix what is, to them, so clearly wrong, are likely to overlook important aspects of the situation and engage in faulty analyses of what must be done to change it.

Don't get me wrong, this is a very good book. It adds an important dimension to our understanding of the place of religion in medicine and medicine in religion. But the authors' reformist zeal obscures aspects of the relationship between those two institutions that may, in the end, help repair the breech. I focus on four points: an incomplete understanding of how the spirituality of immanence interacts with religion, a limited view of how faith operates in medicine and medical science, important parallels between the introduction of ethics and the demise of religion in medicine, and predictable problems with their proposed remedy, "structural pluralism."

\section{Immanence and Religion}

Let's start with the authors' notion of immanence. I think they are on to something very important about the telos of contemporary medicine (p.213):

Gestures of neutrality within medicine hidden behind limited definitions of spirituality and religion do not undo the obvious linkages that become clear when we view medicine through a theological lens aided by functional understandings of religion. Failure to partner with traditional religions elevates immanence to the level of spirituality...recognizing that spirituality and religion are broad constructs identifiable in what is "ultimate concern" or "chief love," then the very framework of "separation" is exposed as an apologetic for a spirituality of immanence.

But in their zeal to expose the problems generated by the spirituality of immanence, the authors fail to see how immanence and traditional religion can be, and are, interwoven, or how an act of care can be interpreted as reflecting either an immanent or a transcendent frame (or both), depending on the orientation of the viewer.

Consider, for example, how the concept of "dispensationalism" is used by conservative Christians to understand the coexistence of miracles and modern medicine. I was raised in the evangelical Christian tradition. Like many children schooled in that view of the world, I was confused 
by the fact that in Biblical times God intervened in nature bringing about miraculous cures for the blind, the lame, the sick - but in the present, in spite of the fervent prayers of the faithful, miracles never, or very rarely occurred. When I asked my elders about this seeming absence of God, the answer I was given was a version of the doctrine of dispensationalism (although I did not recognize it as such): God chooses to be revealed in different ways in different historical dispensations. Before the advent of modern medicine, God used miracles to heal the sick, but in this current dispensation, God has given physicians and medical science the knowledge needed to cure previously incurable diseases. The mundane is actually a miracle. In this tradition, what appears to be a spirituality of immanence - medical science with a singular focus on bodily health - is, in fact, understood to be a spirituality that manifests the presence of God.

The story the authors use to close their book - an account of the care given to a young woman with cancer by a senior physician at a Harvard teaching hospital - offers an example of the difficulty of defining the type of spirituality represented in care that is given. How do we know when care is motivated by an immanent telos or by more transcendent, immaterial ends? The story begins with a depiction of more or less standard care. When the physician enters the young woman's hospital room, she finds her patient in great pain. She recognizes and acknowledges her suffering, and assures her that she will adjust her medications to relieve her pain. But then the doctor does something that takes the occupants of the room - members of the patient's family and two medical students - by surprise (pp. 311-313):

The attending physician stooped down in her skirt and lay on her bare knees before the patient on the hard floor. [She] was now face to face with this sufferer, placing her hand on her quivering body. "I'm so sorry for what you are going through," She said." I'll be back a little later this afternoon to check on you. Hopefully with these new medicines the pain will subside next hour or so..."

Before rising, the doctor gave a slight squeeze with her hand, and slowly whispered, "I am with you."

The authors see in this exchange the creation of "a holy space of human love that contains mystery and power" (p. 313). They express the hope that seeing this kind of care may persuade the students (and others) "that human love, and ultimately divine love, transcend suffering and death." Like the authors, I am touched by this scene, but I also realize that someone whose only concerns were the "immanent" matters of comfort and bodily health may not see anything transcendent in what occurred. Reflecting on this moment of care, the authors observe, "medicine has a sacramental-like nature that at its best points beyond immanent ends toward something mysterious and ultimately healing" (p.313). For them, and for me, this may be true, but it will not be true for everyone.
Faith in the Practice of Medicine and Medical Science

Concern with the dangers of a spiritualty of immanence also limits the authors' investigation of the relationship between religion, faith, and medicine. This results in a nostalgic view of the role of religion in medicine, and insufficient consideration of how faith operates in medicine in terms of both soteriology and epistemology.

The authors convey a nostalgia that suggests a failure to appreciate the way religious traditions change along with changes in society. It is almost as if they have a desire to go back to the days depicted in Fildes' rendition of "The Doctor." In The Weight of Glory, C.S. Lewis (2001) reminds us that nostalgia - a longing for the past - can snare us in days gone by or point us toward the future. He sees in nostalgia a "desire for something that has never actually appeared in our experience," an ache for a better world, and he warns that we should not mistake our memories for this future, better thing: "If they [our memories] are mistaken for the thing itself they turn into dumb idols, breaking the hearts of their worshipers. For they are not the thing itself; they are only the scent of a flower we have not found, the echo of a tune we have not heard, news from a country we have never yet visited." The authors miss the opportunity to see in their nostalgia the possibility to capture the essence of the positive aspects in the historic relationship between medicine and religion, using what they learn to foster a new rapprochement that fits with contemporary society.

The authors' analysis also would benefit from a broader view of the religious/faith elements found in the practice of contemporary medicine. Such a view provides new insights, useful for rethinking and yes, reintroducing, religion to the clinic. Particularly interesting in this regard is the identification of the religious features of secular medicine. Think, for example of the soteriology of medicine. Domaradzki (2013) argues that, like many other secular projects intended to liberate humankind from all misery (he includes the eugenic movement, Marxism and communism, national socialism, pacifism, and ecologism), "medicine promotes a new, secular version of 'salvation'." He refers to this as "'medical soteriology', i.e. the medical promise of 'eternal' health (salus) and happiness and life without diseases and death here on Earth (salus - salvation) and medical monopoly over people's health."

What happens when this source of salvation fails us? We use theodicies to explain the persistence of evil in a world governed by an all-powerful, good, and loving God. When (medical) technology fails, we do something similar. We develop "technodicies," explanations of the failure of the positive and benign force of technology to save us from the evils of illness and infirmity. Because of the immediate and 
practical nature of technology, technodicies differ from the more theological and abstract reasoning found in theodicies. Explanations of the value of technology, in spite of the demonstrable harm they can bring, come in different varieties, including justifications for the continued use of screening technologies associated with high levels of false positives and persistent prescribing of drugs with high "numbers needed to treat."

Perhaps the best example of the former is electronic fetal monitoring (EFM), a standard part of obstetric care even though there is solid evidence that it has no benefit for mothers and babies and that the false positives of EFM are responsible for a significant increase in the rate of unnecessary major abdominal surgery (i.e., cesarean section). All maternity caregivers know this problem with EFM, but that has not changed the fact that this technology is used in nearly all births in the United States (Spector-Bagdady et al. 2017). The widespread use of statins offers a second example of a technodicy. Seen as a panacea for heart disease, in 2013 nearly $28 \%$ of US adults over the age of 40 were taking a statin (Salami et al. 2017). This is in spite of research showing the number needed to treat to prevent a non-fatal heart attack is greater than 200 (i.e., more than 200 people have to take a statin in order to prevent one extra person from having a heart attack). If statins had no harmful side effects, that may be an acceptable number, but statins are associated with muscle problems and new-onset diabetes. (Chou et al. 2016).

In exploring the sacred-secular divide in medicine, the authors distinguish immanent and transcendent epistemologies, the former based in the scientific method and objective fact, the latter based in subjective values and revelation. With healthcare, the authors point out, "claims to objective, universal truths must be grounded in scientifically testable processes" (p. 109). To maintain its authority, medicine must avoid any association with religion in its theories of disease and its practices of cure and care. But we must not forget that faith operates in the scientific realm as well as the religious. The influence of faith on science, the effect of values on the production of knowledge, can be seen at the epistemological and empirical levels.

I will leave it to philosophers to consider the fine points of epistemology, although I offer for your consideration Where the Conflict Really Lies: Science, Religion and Naturalism, Alvin Plantinga's (2012) defense of a theistic understanding of the natural world. Plantinga makes the provocative claim that "it is theism, not naturalism, that deserves to be called 'the scientific worldview.'” (p. 309), noting that science operates on the basis of faith in unprovable assumptions about nature. As a social scientist, I am more interested in the ways values influence the scientific work that informs the practice of medicine. Trudo Lemmens and I show how the "evidence" of evidence-based medicine is distorted by the moneyed interests of pharmaceutical companies - who use the "alchemy of the clinical trial to transform EBM from a challenger to a protector of corporate agendas" - and by physicians whose unshakeable and indiscriminate faith in the value of medical interventions skew their research in favor of those interventions (De Vries and Lemmens 2006).

A deeper understanding of these several dimensions of how faith - in its religious or secular manifestations - operates in the practice of medicine is essential for reintroducing religion in the clinic.

\section{The Rise of Bioethics and the Demise of Religion in Medicine}

It is interesting that the authors give so little attention to the movement of bioethics into medicine. As one interested in exploring the reasons for the emergence of the new profession of "bioethicist," and one who for the last decade and a half has been working in a center for bioethics, I cannot help but see the link between the expanding role of bioethics and the shrinking role of religion in medicine as a critical part of the story of the relationship between medicine and religion.

One explanation for the blossoming of bioethics focuses on the withdrawal of religion from the public sphere. Without religion, how can we trust physicians to do the right thing? In a pluralistic society, how can we even agree on what is the right thing? Enter bioethics. Evans (2012) explains that the seeds of bioethics were planted by theologians, concerned not just with the implications of new technologies, but with the fact that it was scientists who were making ethical claims about the purposes (ends) of those technologies. Gradually, ceding to the demands of a secularizing, pluralistic society, theologians abandoned explicitly religious arguments in their evaluation of science and medicine, opening the door to bioethics, with its set of principles, intended to capture the "common morality."

Abbott (1983) observed a similar process at work in the rise of professional ethics. Using historical data, he showed that when those who entered the learned professions were drawn from the upper classes, there was no need for professional ethics - those admitted to professional training programs were assumed to have a set of ethics that controlled their behavior. When admission procedures became more democratic, professional ethics were needed - no longer did the uniform class (and I would add, religious) background "guarantee" ethical behavior. Professional codes of ethics help secure and preserve the status of an occupation, serving simultaneously as a tool for professional socialization and a symbol to assure the public that members of the profession are trustworthy. In Trusting Doctors, Imber makes a similar argument. He documents how the source of public trust in medicine in the United States shifted from the imprimatur of the (Protestant) clergy to 
reliance on scientific credentials and professional selfregulation.

The incorporation of the story of bioethics and medicine into the authors' account of medicine and religion will allow them to see the fate of efforts to introduce religiouslygrounded ideas to the practice of medicine. Evans (2012, p. 31) shows how what appeared to be an effective strategy for allowing theologians to preserve the voice of religion in bioethical debates - framing their arguments in terms of secular, rather than theological, ends - failed. As a result of this strategy theologians found themselves arguing about the "thinner" questions about the proper means to accomplish ends defined by scientists and physicians (p.31).

\section{Practical Problems with "Structural Pluralism"}

My sociological sensibilities make me wary of "structural pluralism," the authors' proposal for "restoring hospitality to medicine." Their model is designed to promote the "coexistence of multiple communities within shared medical structures consisting of different religions, moral systems, and worldviews." In this system (p.299):

...medicine would partner with religious and/or other moral communities...Each community would have access to organizational and professional structures to incrementally develop its unique, tradition-dependent spiritual viewpoints and practices for the sake of serving and caring for the seriously ill who identify with each tradition. Patients and clinicians would have the opportunity to opt into receiving or providing care from within the tradition, but always free from coercion.

Described as such, the model seems ideal. Therein is the problem. Moving from the ideal to the real exposes at least two significant difficulties with structural pluralism.

First, there are all the predictable complications of bureaucratic organizations, coupled, in this case, with the particular difficulties (read: scandals) of church bureaucracies. Among Americans, trust in religious institutions has fallen to historic lows (Raney et al. 2017). This does not bode well for the public's response to creating religious bureaucracies within medical bureaucracies.

Second, I fear that a general preference for scientifictechnical modes of reasoning will override and defeat the religious organizations of structural pluralism. If I, coming from a Protestant Christian tradition, am in need of a cardiologist, and I discover that the best cardiologist in my region is a Muslim, my inclination will be to seek out that physician, asking God to guide her care for me. With potential patients picking and choosing between respect for transcendent goals (my soul) and respect for immanent goals (my body), structural pluralism will be unsustainable.

\section{Making Medicine Care}

Anyone who has been both an author and a reviewer of books knows it is easy to be a critic. I have expressed concern about those parts of the religion-medicine relationship overlooked by Balboni and Balboni in their enthusiasm for fixing health care, but I am convinced that they show us something very important about the state of our lives and our medical system.

While I was preparing this review, I came across an interesting essay by the columnist Andrew Sullivan (2018). Interesting because it aligned so closely with the message of this book. Sullivan observes, "we're mistaken if we believe that the collapse of Christianity in America has led to a decline in religion." He goes on:

Everyone has a religion. It is, in fact, impossible not to have a religion if you are a human being. It's in our genes and has expressed itself in every culture, in every age, including our own secularized husk of a society. By religion, I mean something quite specific: a practice not a theory; a way of life that gives meaning, a meaning that cannot really be defended without recourse to some transcendent value, undying "Truth" or God (or gods).

Mirroring the analysis of Balboni and Balboni, he notes how the modern world protects us from "existential moments" with a plethora of diversions (Netflix, air-conditioning, sex apps, Alexa, kale, Pilates, Spotify, Twitter), preventing a confrontation with ultimate meaning "until a tragedy occurs, a death happens, or a diagnosis strikes."

The question remains, "How can we capture the religious sensibility that we all share, and use it to provide more caritas in medicine?" Hostility to Hospitality shows us that this is something we all desire and offers a roadmap to get there, but it fails to take into account a critical aspect of the lived experience of religion in America. Speaking of Evangelicals, Sullivan says:

...many Evangelicals are among the holiest and most quietly devoted people out there... But their leaders have turned Christianity into a political and social identity, not a lived faith, and much of their flock - a staggering 81 percent voted for Trump - has signed on. They have tribalized a religion explicitly built by Jesus as anti-tribal. They have turned to idols - including their blasphemous belief in America as God's chosen country. They have embraced wealth and nationalism as core goods, two ideas utterly anathema to Christ. They are indifferent to the destruction of the creation they say they believe God made. 
I ask the authors: how can we separate the wheat from the religious chaff, bringing to the work of medicine whatever is true, honorable, just, pure, lovely, gracious, and excellent (Phillipians 4:8, RSV)? That is where our work lies.

Open Access This article is distributed under the terms of the Creative Commons Attribution 4.0 International License (http:// creativecommons.org/licenses/by/4.0/), which permits unrestricted use, distribution, and reproduction in any medium, provided you give appropriate credit to the original author(s) and the source, provide a link to the Creative Commons license, and indicate if changes were made.

\section{Further Reading}

Abbott, A. 1983. Professional ethics. American Journal of Sociology, 88, $855-885$.

Berger, P. 1963. Invitation to sociology. New York:Doubleday.

Chou, R., Dana, T., Blazina, I., Daeges, M., \& Jeanne, T. L. 2016. Statins for Prevention of Cardiovascular Disease in Adults: Evidence Report and Systematic Review for the US Preventive Services Task Force. JAMA., 316(19), 2008-2024.

De Vries, R., \& Lemmens, T. 2006. The subjectivity of objective evidence: The social and cultural shaping of medical evidence. Social Science and Medicine, 62(11), 2694-2706.

Domaradzki, J. 2013. Extra Medicinam Nulla Salus. Medicine as a Secular Religion. Polish Sociological Review, 1, 21-38.

Evans, J. 2012. The History and Future of Bioethics: A Sociological View. New York: Oxford.

Imber, J. 2008. Trusting Doctors: The Decline of Moral Authority in American Medicine. Princeton NJ:Princeton University Press.
Jewson, N. D. 1976. The Disappearance of the Sick-Man from Medical Cosmology, 1770-1870. Sociology, 10(2), 225-244.

Lewis, C. S. 2001. The Weight of Glory. New York:HarperCollins.

Platinga, A. 2012. Where the Conflict Really Lies: Science, Religion and Naturalism. New York:Oxford University Press.

Raney, A., Cox, D., Jones, R. P., 2017. Searching for Spirituality in the U.S.: A new Look at the Spiritual but Not Religious. https://www. prri.org/research/religiosity-and-spirituality-in-america/. Accessed 9 March 2019.

Salami, J. A., Warraich, H., Valero-Elizondo, J., Spatz, E. S., Desai, N. R., Rana, J. S., Virani, S. S., Blankstein, R., Khera, A., Blaha, M. J., Blumenthal, R. S., Lloyd-Jones, D., \& Nasir, K. 2017. National Trends in Statin Use and Expenditures in the US Adult Population From 2002 to 2013 Insights From the Medical Expenditure Panel Survey. JAMA Cardiology, 2(1), 56-65.

Spector-Bagdady, K., De Vries, R., Harris, L. H., \& Low, L. K. 2017. Stemming the Standard-of-Care Sprawl: Clinician Self-Interest and the Case of Electronic Fetal Monitoring. Hastings Center Report., 47(6), 16-24.

Sullivan, A. 2018. America's New Religions. http://nymag.com/ intelligencer/2018/12/andrew-sullivan-americas-new-religions. html. Accessed 9 March 2019.

Raymond De Vries is Associate Director at the Center for Bioethics and Social Sciences in Medicine at the University of Michigan and is a Professor in the Department of Learning Health Sciences and the Department of Obstetrics and Gynecology. He is also visiting professor at CAPHRI School for Public Health and Primary Care, University of Maastricht, the Netherlands.

Publisher's Note Springer Nature remains neutral with regard to jurisdictional claims in published maps and institutional affiliations. 